\title{
EFEKTIVITAS PENERAPAN PRINSIP-PRINSIP KEPEMIMPINAN KEPALA SEKOLAH TERHADAP PENINGKATAN MUTU LAYANAN ADMINISTRASI PENDIDIKAN
}

\author{
Suarga \\ Fakultas Tarbiyah dan Keguruan \\ Universitas Islam Negeri Alauddin Makassar
}

\begin{abstract}
:
Globalization in the world of education is increasingly stronger demands on the quality of education. Quality education demands creative, innovative and productive individuals that can be said that only nations with quality education can compete globally. Educational services as a category of service (service) implemented by the institution of education or educational unit for and for the benefit of the community. Education should be oriented on improving the quality of services to create a fun and satisfying educational process that encourages learners to the spirit of learning which ultimately is expected to produce quality educational output.

Service is a process of providing services (service delivery) from producers to customers (costumer). Quality services are services that meet or exceed the needs that service users expect. Activities to manage resources to support quality educational processes require professional, organized and planned educational management or administration. Therefore, the leadership role of the principal is very important. Leadership of principals is one of the determinants of the success of a school. Therefore, the principal must understand the roles and responsibilities it carries. According to Wahjosumijo there are two important roles of the principal, namely the principal acts as a central force that becomes the driving force of social life and the principal must understand his duties and functions for the success of the school, and has a concern for staff and students
\end{abstract}

Keywords: Leadership, Headmaster, Quality of Administration Service

\section{LATAR BELAKANG}

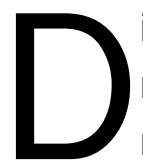

i antara dampak globalisasi dalam dunia pendidikan adalah semakin menguatnya tuntutan terhadap mutu pendidikan. Pendidikan yang bermutu menuntut individu-individu yang kreatif, inovatif dan produktif sehingga dapat dikatakan bahwa hanya bangsa dengan pendidikan bermutu yang dapat bersaing secara global.

Pendidikan termaksuk kategori pelayanan jasa (service) yang dilaksanakan oleh lembaga penyelenggaraan pendidikan atau satuan pendidikan bagi dan untuk kepentingan masyarakat. Pendidikan harus diorientasikan pada peningkatan mutu pelayanan agar tercipta proses pendidikan yang menyenangkan dan memuaskan sehingga mendorong peserta didik untuk semangat belajar yang pada akhirnya diharapkan dapat menghasilkan output pendidikan yang bermutu. Undang-undang No 20 Tahun 2003 tentang sistem pendidikan Nasional mengamanatkan 
pendidikan adalah usaha sadar dan terencana untuk mewujudkan suasana belajar dan proses pembelajaran agar peserta didik secara aktif mengembangkan potensi dirinya untuk memiliki kekuatan spiritual keagamaan, pengendalian diri, kepribadian, kecerdasan, ahlak mulia serta keterampilan yang diperlukan dirinya, masyarakat bangsa dan negara (Hasbullah, 2012:4). Salah satu implikasi dari rumusan pendidikan tersebut adalah perlunya peningkatan mutu pendidikan dalam berbagai aspek, jenis, jenjang dan satuan pendidikan yang terhimpun dalam sistem pendidikan nasional.

Layanan merupakan sebuah proses pemberian jasa (service delivery) dari produsen kepada pelanggan (costumer). Layanan yang bermutu adalah layanan yang dapat memenuhi atau bahkan melebihi kebutuhan yang diharapkan oleh pengguna jasa layanan (Ridwan, 2013:5). Menurut Kotler kepuasan adalah hasil yang dirasakan oleh konsumen yang mengalami kinerja sebuah lembaga yang sesuai dengan harapannya.

Mutu layanan merupakan faktor penting dan integral dalam pendidikan. Menurut Colby \& Witt (2000:30) mutu layanan pendidikan merupakan outcome dari interaksi antara lingkungan belajar yang kondusif, peserta didik dan pendidik, materi pembelajaran (materi, kurikulum dan standar) dan proses pembelajaran di kelas.

Menurut Srinadi dan Nilasukmawati pengukuran mutu pelayanan merupakan elemen penting dalam menyediakan pelayanan yang lebih baik, lebih efisien dan lebih efektif. Oleh karena itu, mutu pelayanan harus dimulai dari kebutuhan konsumen akan pelayanan dan berakhir pada persepsi konsumen akan mutu pelayanan yang diberikan.

Banyak faktor yang menentukan mutu layanan di sekolah, menurut Tilaar faktor-faktor tersebut antara lain, dedikasi dan disiplin, jujur, inovatif, tekun, ulet, sumber daya manusia dan kepemimpinan (Tilaar, 2001:57).

Aktifitas mengatur sumber daya untuk menunjang berlangsungnya proses pendidikan yang bermutu memerlukan pengelolaan atau administrasi pendidikan secara profesional, terorganisir dan terencana. Oleh karena itu peran kepemimpinan kepala sekolah sangat penting.

Kepemimpinan pendidikan adalah suatu proses mempengaruhi, mengkoordinasi, dan menggerakan perilaku orang lain serta melakukan perubahan kearah yang lebih positif dalam mengupayakan keberhasilan pendidikan.

Selain definisi diatas ditemukan pula istilah kepemimpinan dalam terminology Islam. Dalam Al-Qur'an istilah kepemimpinan diungkapkan dengan istilihah khalifah. Sebagaimana firman Allah pada qur'an surah Al-baqarah sebagai berikut :

Artinya:

Ingatlah ketika Tuhanmu berfirman kepada para malaikat: "Sesungguhnya Aku hendak menjadikan seorang khalifah di muka bumi." (Q.S Al-Baqarah: 30) 
Selain kata khalifah disebut juga kata ulil amri. Kata ulil amri berarti pemimpin tertinggi dalam masyarakat islam, sebagaimana firman Allah swt, sebagai berikut:

Artinya:

Hai orang-orang yang beriman, taatilah Allah dan taatilah Rasul (nya), dan ulil amri di antara kamu. (Q.S An-nisaa': 59)

Berdasarkan ayat Al-qur'an di atas, maka dapat disimpulkan bahwa kepemimpinan dalam islam itu adalah kegiatan menuntun, membimbing, memandu dan menunjukkan jalan yang diridhai Allah swt.

Kepala sekolah adalah tenaga edukatif yang berperan untuk mengatur dan mengelola sekolah agar terciptanya suasana yang kondusif sehingga tercapai tujuan pendidikan secara efektif dan efisien.

Sebagai pemimpin, kepala sekolah memiliki posisi sentral dalam menciptakan dan mengendalikan mutu sekolah yang dipimpinnya. Kepala sekolah dapat menentukan arah dan tujuan sekolah. Kegagalan maupun keberhasilan sekolah ditentukan oleh kepala sekolah.

Kepemimpinan kepala sekolah merupakan salah satu penentu keberhasilan suatu sekolah. Oleh karena itu, kepala sekolah harus memahami peran dan tanggung jawab yang diembannya. Menurut Wahjosumijo (2002:82) ada dua peranan penting kepala sekolah, yaitu kepala sekolah berperan sebagai kekuatan sentral yang menjadi kekuatan penggerak kehidupan sosial dan kepala sekolah harus memahami tugas dan fungsinya demi keberhasilan sekolah, serta memiliki kepedulian kepada staf dan siswa.

Peranan strategis kepala sekolah dalam meningkatkan mutu sekolah khususnya pelayanan yang bermutu yaitu dengan memenuhi kepuasan dari pelanggan. Kepuasan pelanggan meliputi banyak hal, dari hasil observasi yang dilakukan, peneliti melihat bahwa meskipun pelayanan yang dinilai beberapa orang sudah memenuhi harapan ada juga beberapa dari responden yang memiliki pendapat bahwa pelayanan masih belum memenuhi harapan mereka.

Berdasarkan penelitian diatas, maka penulis tertarik untuk mengambil penelitian dengan judul "Evektifitas Penerapan Prinsip-Prinsip Kepemimpinan Kepala Sekolah Terhadap Peningkatan Mutu Layanan Administrasi Pendidikan Di SMA Islam Al-Azhar 12 Makassar Sesuai Dengan Konsep TQM (Total Quality Management)."

\section{PERMASALAHAN}

1. Bagaimana penerapan prinsip-prinsip kepemimpinan Kepala Sekolah?

2. Bagaimana prinsip mutu layanan administrasi pendidikan?

3. Bagaimana efektivitas penerapan prinsip-prinsip kepemimpinan Kepala Sekolah terhadap peningkatan mutu layanan administrasi pendidikan? 


\section{PEMBAHASAN MASALAH}

\section{Tinjauan Tentang Efektivitas Prinsip-Prinsip Kepemimpinan Kepala Sekolah}

\section{a. Pengertian Kepemimpinan}

Kepemimpinan secara harfiah berasal dari kata pimpin. Kata pimpin mengandung pengertian mengarahkan, membina atau mengatur, menuntun dan juga menunjukkan ataupun mempengaruhi. Pemimpin mempunyai tanggung jawab baik secara fisik maupun spiritual terhadap keberhasilan aktivitas kerja dari yang dipimpin.

Kepemimpinan merupakan salah satu faktor yang sangat penting dalam suatu organisasi karena sebagian besar keberhasilan dan kegagalan suatu organisasi ditentukan oleh kepemimpinan dalam organisasi tersebut.

Menurut sondang P. Siagian kepemimpinan merupakan motor penggerak dari semua sumber-sumber dan alat-alat (resource) yang tersedia bagi suatu organisasi. Tugas dasar pemimpin adalah membentuk dan memelihara lingungan dimana manusia bekerja sama dalam suatu kelompok yang terorganisir dengan baik, menyelesaikan tugas mencapai tujuan yang telah ditetapkan (Sagala, 2013:143).

Menurut Bass, kepemimpinan merupakan suatu interaksi antara anggota suatu kelompok sehingga pemimpin merupakan agen pembaharu, agen perubahan, orang yang perilakunya akan lebih mempengaruhi orang lain daripada perilaku orang lain yang mempengaruhi mereka, dan kepemimpinan itu sendiri timbul ketika satu anggota kelompok mengubah motivasi kepentingan anggota lainnya dalam kelompok (Engkoswara dan Aan Komariah, 2012:177).

Kepemimpinan merupakan suatu produk dari interaksi individu-individu dalam suatu kelompok/organisasi. Oleh karena itu, kepemimpinan dapat diartikan suatu bentuk persuasi, pembinaan, dan pengembangan individu dan atau kelompok orang-orang tertentu melalui suatu interaksi (human relation) dan motivasi yang tepat agar mereka mau bekerja sama untuk memajukan tujuan organisasi. Hal ini sejalan dengan pandangan Edwin A. Locke yang mengemukakan bahwa kepemimpinan adalah, "proses membujuk (inducting) orang-orang lain untuk mengambil langkah menuju suatu sasaran bersama. Definisi ini mengategorikan tiga elemen (Suharsaputra, 2013:128) yaitu:

1) Kepemimpinan merupakan suatu konsep relasi (relation concept)

2) Kepemimpinan merupakan suatu proses

3) Kepemimpinan harus membujuk orang-orang lain untuk mengambil tindakan

George R. Terry mengartikan bahwa kepemimpinan adalah aktivitas untuk mempengaruhi orang-orang supaya diarahkan mencapai tujuan organisasi. Kepemimpinan meliputi proses mempengaruhi dalam menentukan tujuan organisasi, memotivsi perilaku pengikut untuk mencapai tujuan, mempengaruhi untuk memperbaiki kelompok dan budayanya. 
Martinis Yamin dan Maisah kepemimpinan adalah suatu proses mempengaruhi yang dilakukan oleh seseorang dalam mengelola anggota kelompoknya untuk mencapai tujuan organisasi. Kepemimpinan merupakan bentuk strategi atau teori memimpin yang tentunya dilakukan oleh orang yang biasa kita sebut sebagai pemimpin. Pemimpin adalah seseorang dengan wewenang kepemimpinannya mengarahkan bawahannya untuk mengerjakan sebagian dari pekerjaannya dalam mencapai tujuan.

Dari beberapa pendapat diatas terlihat bahwa kepemimpinan merupakan aktivitas membujuk orang lain dalam suatu kelompok agar mau bekerja sama untuk mencapai tujuan bersama yang kegiatannya meliputi membimbing, mengarahkan, memotivasi, tindakan atau tingkah laku orang lain. Ini berarti bahwa konstribusi kepemimpinan bagi perkembangan organisasi akan ditentukan oleh bagaimana seorang pemimpin berperan dalam menjalankan fungsinya bagi kehidupan organisasi. Faktor keberhasilan seorang pemimpin salah satunya tergantung dengan tehnik kepemimpinan yang dilakukan dalam menciptakan situasi sehingga menyebakan orang yang dipimpinnya timbul kesadarannya untuk melaksanakan apa yang dikehendaki. Dengan kata lain, efektif atau tidaknya seorang pemimpin tergantung dari bagaimana kemampuannya dalam mengelola dan menerapkan pola kepemimpinannya sesuai dengan situasi dan kondisi organisasi tersebut.

\section{Efektivitas Kepemimpinan Kepala Sekolah}

Menurut A. Dale Timpe dalam Leadership mengutip pendapat Gary K. Hines menyatakan bahwa seorang pemimpin yang efektif harus memperhatikan dengan baik orang maupun produksi. Ini berarti bahwa ia harus menciptakan iklim agar orang dapat berkerja sama untuk mendapatkan hasil yang bermutu sehingga akan memunculkan kepuasan dalam berkerja.

Kepala sekolah sebagai motor penggerak penentu arah kebijakan sekolah serta menentukan bagaimana tujuan pendidikan di sekolah yang dipimpinnya dapat direalisasikan, dituntut untuk senantiasa meningkatkan kinerja. Peningkatan kinerja dapat ditunjukan dengan mewujudkan tujuan pendidikan yang efektif dan efisien. Sehubungan dengan itu maka diperlukan efektivitas kepemimpinan kepala sekolah.

Mulyasa (2004:126) memberikan Kriteria pemimpinan kepala sekolah yang efektif sebagai berikut:

a. Mampu memberdayakan guru untuk melaksanakan proses pembelajaran dengan baik, lancar dan produktif.

b. Menyelesaikan tugas dan pekerjaan sesuai dengan waktu yang telah ditetapkan. 
c. Menjalin hubungan yang harmonis dengan masyarakat, sehingga dapat melibatkan mereka secara aktif dalam rangka mewujudkan tujuan pendidikan di sekolah.

d. Menerapkan prinsip kepemimpinan yang sesuai dengan tingkat kedewasaan guru dan pegawai di sekolah.

e. Bekerja dengan tim manajemen

f. Mewujudkan tujuan sekolah secara produktif sesuai dengan ketentuan yang ditetapkan.

Kepemimpinan kepala sekolah yang efektif lebih mendasar pada tugas yang akhirnya akan menghasilkan penilaian positif terhadap keberhasilan kerja. Selain itu, kepemimpinan kepala sekolah yang efektif mendasar pada orang dan menempatkan guru, staf administrasi dan siswa pada proporsinya masing-masing, berpengaruh pada efektivitas kerja lebih baik. Kepemimpinan kepala sekolah yang efektif seharusnya mewujudkan orientasi pada tugas dan memandang guru, staf administrasi, serta siswa merupakan bagian penentu keberhasilan pendidikan.

Efektivitas kepemimpinan kepala sekolah dipengaruhi banyak faktor. Menurut H. Jodeph Reitz (Dalam Fattah, 2004:98-100) faktor-faktor yang mempengaruhi efektivitas kepemimpinan meliputi:

a. Kepribadian

b. Pengharapan dan perilaku atasan

c. Karakteristik

d. Kebutuhan tugas

e. Iklim dan kebijakan organisasi

f. Harapan dan perilaku rekan

Berdasarkan faktor-faktor tersebut bahwa kesuksesan pemimpin dalam aktivitasnya dipengaruhi oleh faktor-faktor yang dapat menunjang untuk berhasilnya suatu kepemimpinan, oleh sebab itu suatu tujuan akan tercapai apabila terjadinya keharmonisan dalam hubungan atau interaksi yang baik antara atasan dan bawahan, disamping dipengaruhi olehh latar belakang yang dimiliki pemimpin, seperti motivasi untuk berprestasi, kedewasaan dan keleluasaan dalam hubungan sosial dengan sikap-sikap hubungan manusiawi.

\section{Prinsip-Prinsip Kepemimpinan}

Prinsip-prinsip kepemimpinan pendidikan diantaranya yaitu :

a. Prinsip pelayanan, bahwa kepemimpinan sekolah harus menerapkan unsurunsur pelayanan dalam kegiatan operasional sekolahnya.

b. Prinsip persuasi, pemimpin dalam menjalankan tugasnya harus memperhatikan situasi dan kondisi setempat demi keberhasilan keberhasilan kepemimpinannya yang sedang dan yang akan dilaksanakan. 
c. Prinsip bimbingan, pemimpin pendidikan hendaknya membimbing peserta didik kearah tujuan yang ingin dicapai sesuai dengan perkembangan peserta didik yang ada dilembaganya.

d. Prinsip efisiensi, mengarah pada cara hidup yang ekonomis dengan pengeluaran sedikit untuk memperoleh keuntungan yang sebesar-besarnya.

e. Prinsip berkesinambungan, agar pemimpin pendidikan ini diterapkan tidak hanya pada satu waktu saja, tetapi perlu secara terus menerus.

Menurut Toman Sony Tambunan (2015:67-71) prinsip-prinsip kepemimpinan yaitu:

a. Melayani

Prinsip pertama yang paling penting harus diketahui oleh seorang pemimpin adalah memberikan pelayanan yang baik sebagai tujuan utama. Dalam teori kepemimpinan, pemimpin yang efektif harus bisa melayani guna memenuhi kebutuhan dan keinginan, sehingga meningkatkan kesejahteraan orang-orang yang dipimpinnya. Dengan prinsip melayani, seorang pemimpin akan lebih mengutamakan kepentingan orang-orang yang dipimpinnya (para bawahan, pengikutnya, masyarakat umum) dibanding lebih mendahulukan kepentingan pribadi atau kelompok.

Menurut Northouse (2013:207) kepemimpinan yang melayani merupakan pendekatan yang berfokus pada kepemimpinan dari sudut pandang pemimpin dan perilakunya, empati serta mengembangkan mereka. Pemimpin yang melayani mengutamakan pengikut, memberdayakan, dan membantu dalam mengembangkan kapasitas pribadi secara penuh dari para pengikutnya. Menurut Larry C. Spears, mengacu pada pemikiran Greenleaf, terdapat sepuluh karakteristik yang menjadi inti pengembangan kepemimpinan yang melayani yaitu:

1) Mendengarkan (Listening), Kemampuan ini penting bagi pemimpin yang melayani, pemimpin ini perlu dikuatkan dengan komitmen yang kuat untuk mendengarkan orang lain dengan sungguh-sungguh. Pemimpin yang melayani mencoba untuk mengidentifikasikan keinginan dari sebuah kelompok dan membantu mengklarifikasikan keinginan tersebut, dengan cara menyimak.

2) Empathy, artinya pemimpin yang melayani menunjukkan bahwa mereka benarbenar memahami apa yang dipikirkan dan dirasakan pengikut.

3) Menyembuhkan (Healing), pemimpin yang melayani peduli dengan kesehatan pribadi pengikutnya.

4) Penyadaran/peningkatan kesadaran (Awareness), Kesadaran umum dan terutama kesadaran diri, memperkuat pemimpin yang melayani. Kesadaran juga membantu seseorang dalam memahami persoalan yang berhubungan dengan etika dan nilai.

5) Memiliki sifat persuasif (Persuasive), persuasi adalah komunikasi yang jelas dan ulet yang meyakinkan orang lain untuk berubah. 
6) Koseptualitas (Konseptualization), merujuk pada kemampuan individu untuk menjadi orang yang berpandangan jauh ke depan bagi suatu organisasi, dan menberi pemahaman yang jelas akan tujuan dan arah.

7) Peramalan (Foresight), meliputi kemampuan pemimpin yang melayani untuk mengetahui masa depan.

8) Tugas untuk mengurus (Stewardship), artinya memiliki tanggung jawab untuk peran yang dipercayakan kepada pemimpin.

9) Memiliki komitmen untuk menghasilkan proses pembelajaran (commitment to the growth of people), pemimpin yang melayani percaya bahwa orang lain mempunyai nilai instrinsik melebihi kontribusi nyata mereka sebagai karyawan atau pekerja. Sebagai hasilnya, pemimpin yang melayani berkomitmen secara mendalam pada pengembangan dan masing-masing dan setiap individu dalam institusi. Pemimpin yang melayani menyadari tanggung jawab yang luar biasa untuk melakukan semua hal yang memungkinkan untuk membantu pembelajaran sumber daya manusia.

10) Membangun dan memperkuat komunitas (building community)

b. Membuat keputusan

Pembuatan keputusan merupakan tugas paling utama yang harus dilakukan oleh seorang pemimpin. Membuat keputusan merupakan fungsi-fungsi dasar dari berpikir, dimana proses penggunaan pikiran dalam mengarahkan pada suatu tindakan untuk menetapkan suatu pilihan. Pembuatan keputusan dan pemecahan masalah adalah salah satu tugas dari seorang pemimpin. Seorang pemimpin harus mampu melakukan pebyelesaian masalah dan memberikan keputusan yang cerdas. Ada lima langkah dalam proses pengambilan keputusan yaitu:

1) Mengidentifikasi masalah dan peluang

2) Pengumpulan dan analisis data yang relavan

3) Pengembangan dan evaluasi alternatif

4) Pemilihan alternatif terbaik

5) Implementasi keputusan dan evaluasi terhadap hasil-hasil

c. Keteladanan

Pemimpin yang menunjukkan pengaruh yang baik dan memberikan nilai positif bagi organisasi dan para pengikutnya, akan mampu menjadi teladan bagi yang dipimpinnya. Keteladanan seorang pemimpin ditunjukkan melalui sikap dalam memberikan inspirasi, membimbing dan memotivasi para bawahan, memiliki kemampuan luas, kreatif, visioner, bekerja secara jujur dan ikhlas, serta memiliki perhatian dan kepedulian. Pemimpin harus menjadi panutan, dan bisa diikuti kepribadiannya bagi orang-orang yang dipimpinnya.

d. Bertanggung jawab

Menjadi pemimpin merupakan tanggung jawab besar yang harus diemban sebagai bentuk dari amanah, dukungan atau kepercayaan orang lain yang memiliki 
harapan kepada seorang pemimpin tersebut untuk melakukan perubahan yang lebih baik dari keadaan sebelumnya. Tanggung jawab seorang pemimpin terdiri dari dua tahap yaitu:

1) Bertanggungjawab menyelesaikan tugas

2) Mempertanggungjawabkan kepada atasan atau kepada orang yang mendelegasikan wewenang mengenai hasil yang telah dicapai.

e. Bekerja sama

Pemimpin yang efektif akan mampu menciptakan budaya kerja sama tim yang baik diantara anggota organisasi, melakukan komunikasi yang efektif dengan para bawahan, serta menciptakan lingkungan kerja yang baik. Dengan terciptanya kerja sama yang baik, maka seluruh pekerjaan akan diselesaikan dengan tepat waktu, tujuan yang diinginkan dapat dicapai. West menetapkan indikator-indikator kerja sama tim yaitu:

1) Tanggung jawab secara bersama menyelesaikan pekerjaan, yaitu dengan pemberian tanggung jawab dapat tercipta kerja sama yang baik.

2) Saling berkontribusi, yaitu dengan saling berkontribusi baik tenaga maupun pikiran akan tercapainya kerja sama

3) Pengarahan kemampuan secara maksimal, yaitu dengan mengarahkan kemampuan masing-masing anggota tim secara maksimal, kerja sama akan lebih kuat dan berkualitas.

f. Menciptakan perubahan

Pemimpin harus membuat terobosan-terobosan baru, sehingga tercapaianya suatu pembaharuan fundamental baik di tubuh organisasi, produk atau jasa, maupun bagi orang-orang yang dipimpinnya. Pemimpin yang memiliki inovatif dan kreatifitas akan menghindari pola kerja yang bersifat rutinitas (monoton sehingga tidak memberikan arah perkembangan yang baik bagi yang dipimpinnya. Dengan kreatifitas pemimpin juga akan berani menciptakan peluang-peluang dan berani menghadapi tantangan-tantangan besar dalam mencapai tujuan yang diinginkan.

Berdasarkan uraian di atas maka yang dimaksud efektivitas penerapan prinsip-prinsip kepemimpinan kepala sekolah yaitu dengan menerapkan prinsip melayani, prinsip mengambil keputusan, prinsip keteladanan, prinsip kerja sama dan prinsip menciptakan perubahan.

\section{DAFTAR PUSTAKA}

Arikunto, Suharsimi. Metode Penelitian Pendidikan. Surabaya: Karya Abditama, 1997.

Azwar, Saifuddin. Penyusunan Skala Psikologi. Yogyakarta; Pustaka Pelajar, 1999.

Colby J. \& M. Witt. Defining Quality In Education. New York: United Nations 
Children's fun, 2000.

Daryanto dan Ismanto Setyobudi, Konsumen dan Pelayanan Prima. Yogyakarta: Gava Media, 2014.

Engkoswara dan Aan Komariah. Administrasi pendidikan. Bandung: Alfabeta, 2012.

Fattah, Nanang. Landasan Manajemen Pendidikan. Bandung: Remaja Rosdakarya, 2004.

hasan, Iqbal. pokok-pokok materi statistik I: Statistik deskrptif. Jakarta: Bumi Aksara., 2001.

Hasbullah. Dasar-dasar IImu Pendidikan. Jakarta: Rajawali Pers, 2012.

Lusi Rakasiwi. "Analisis Kualitas Pelayanan Akademik Dan Ketersediaan Sarana Akademik Biro Administrasi Akademik Terhadap Kepuasan Mahasiswa Universitas Muhammadiyah Surakarta 2015", Skripsi. Surakarta: Fak. Keguruan dan IImu Pendidikan, 2015.

M. A, J Supranto. Metode Ramalan Kuantitatif Untuk Perencanaan Ekonomi dan Bisnis. Jakarta: Rineka Cipta.

Margono, S. Metodologi Penelitian Pendidikan . Jakarta: Rineka Cipta, 2007.

M. Echols, Jhon dan Hasan Sadily. Kamus Inggris-Indonesia. Jakarta: Gramedia, 1997.

Moh Ridwan, Asep "Pengaruh Kepemimpinan Kepala Madrasah dan Pemanfaatan Fasilitas Pendidikan Terhadap Mutu Layanan Akademik Pada Madrasah Aliyah Negeri Di Kabupaten Cianjur", Skripsi. Jakarta: Universitas Pendidikan Indonesia, 2013.

Mulyasa, E. Manajemen Berbasis Sekolah. Bandung: PT. Remaja Rosdakarya, 2004.

Northouse, G. Peter. Kepemimpinan: Teor dan Praktek. Cet. VI; Jakarta: Penerbit Indeks, 2013.

P. Siagian, Sondang. Administrasi Pembangunan. Jakarta: Gunung Agung, 1982.

Pringgodigdo. Ensiklopedi Umum. Yogyakarta: Kanisius, 1993.

Riduwan dan Akdon. Rumus dan Data dalam Analisis Statistika. Bandung: Alfabeta, 2007.

Sagala, Syaiful. Kemampuan Profesional Guru dan Tenaga Kepemimpinan, Memberdayakan Guru, Tenaga Kependidikan dan Masyarakat dalam Manajemen Sekolah. Bandung: Alfabeta, 2009.

Salis, Edward. Total Quality Management in Education: Model, Tehnik dan Inplementasinya. Cet. I; Yogyakarta: IRCiSoD, 2015.

"Corporate Planning in an FE College", Education Management and Administration, Vol. 18, No. 2, 1990. Gray, Lynton, Foreword to Sallis, Edward 
and Peter Hingley. Total Quality Management, Coombe Lodge Report, Vol. 13, No 1, Blagdom, the Staff College, 1992.

Sony Tambunan, Toman. Pemimpin dan Kepemimpinan. Cet I; Yogyakarta: Graha IImu, 2015.

Sugiyono. Metode Penelitian Pendidikan: Pendekatan Kuantitatif, Kualitatif, dan R\&D. Bandung: Alfabeta, 2015.

Metodologi Penelitian Pendidikan. Bandung: Alfabeta , 2011.

Surip. “Efektivitas Kepemimpinan Kepala Sekolah", Tesis. Surakarta: Program Pascasarjana, 2005.

Tilaar, H. A. R. AGENDA Reformasi Pendidikan Nasional. Jakarta, Indonesiatera, 2001.

Suharsaputra, Uhar. Administrasi Pendidikan Edisi revisi. Bandung: PT Refika Aditama, 2013.

Usman, Husaini. Manajemen: Teori, Praktek, dan Riset Pendidikan. Cet. II; Jakarta: Bumi Aksara, 2010. 